\title{
Deteksi Surra yang Disebabkan Trypanosoma evansi pada Kerbau di Kabupaten Pandeglang, Provinsi Banten
}

\section{(Surra Detection Caused Trypanosoma evansi in Buffaloes in Pandeglang District of Banten Province)}

\author{
Wardhana AH, Sawitri DH \\ Balai Besar Penelitian Veteriner, Jl. R.E. Martadinata No. 30, Bogor \\ wardhana24id@yahoo.com
}

\begin{abstract}
Banten Province has been proposed as a national buffaloes farming center in Indonesia. Nevertheless, the existence of Surra caused by blood protozoan parasite, Trypanosoma evansi, remains a major problem for the livestock in the area. A robust diagnostic Surra might not rely on one certain method because each method has a different sensitivity level. The aim of the study was to detect Surra in buffaloes using various diagnostic methods. A total of 50 buffaloes blood samples collected from three subdistricts in Banten Province were tested using different diagnostic methods i.e. Giemsa- stained thin blood smear, Micro-haematocrite Centrifugation Technique (MHCT), serological test using Card Agglutination Technique for T. evansi (CATT T. evansi) and PCR with 2 genetical markers, ITS-1 and TBR1/2. The results demonstrated that $16 \%$ was positive for blood smear and MHCT, while PCR gave positive response for $50 \%$. The highest positive result was obtained from serological test for $84 \%$. The low positive result from blood smear and MHCT methods was related to the low parasitemia level in the host blood, so that it needs to be confirmed using PCR or serological tests possessing a higher sensitivity. Accordingly, the false-negative result of Surra might be hindered and a treatment strategy of Surra can be decided properly.
\end{abstract}

Key words: Surra, Trypanosoma evansi, diagnosis, Banten

\begin{abstract}
ABSTRAK
Provinsi Banten telah diusulkan sebagai salah satu pusat pembibitan kerbau nasional. Namun demikian, keberadaan Surra yang disebabkan oleh protozoa darah Trypanosoma evansi masih menjadi kendala dalam pengembangan komoditas ternak ini. Penegakan Surra tidak dapat hanya didasarkan pada satu teknik diagnosa saja karena masing-masing teknik memiliki perbedaan tingkat sensitivitas. Tujuan penelitian ini adalah untuk mengetahui hasil deteksi Surra pada kerbau yang diuji menggunakan beberapa teknik diagnose. Sebanyak 50 sampel darah kerbau dikoleksi dari tiga kecamatan di Kabupaten Pandeglang - Banten. Masing-masing sampel diuji dengan empat teknik diagonosa yang berbeda, yaitu ulas darah dengan pewarnaan Giemsa, Micro-haematocrite Centrifugation Technique (MHCT), uji serologis dengan Card Agglutination Technique for T. evansi (CATT T. evansi) serta uji PCR dengan marka genetik ITS-1 dan TBR1/2. Hasil penelitian menunjukkan bahwa sebanyak $16 \%$ sampel dideteksi positif Surra berdasarkan teknik diagnosa ulas darah dan MHCT, sedangkan hasil uji PCR memberikan nilai positif sebesar 50\%. Adapun uji serologis CATT T. evansi menunjukkan hasil positif yang paling tinggi, yaitu $84 \%$. Rendahnya hasil positif pada ulas darah dan MHCT diduga karena rendahnya tingkat parasitemia pada tubuh kerbau,
\end{abstract}


sehingga perlu dikonfirmasi dengan teknik PCR dan uji serologis yang memiliki tingkat sensitivitas lebih tinggi. Dengan demikian, hasil deteksi negatif palsu Surra dapat dihindari dan strategi pengobatan dapat dilakukan dengan cepat dan tepat.

Kata kunci: Surra, Trypanosoma evansi, diagnosis, Banten

\section{PENDAHULUAN}

Kerbau adalah salah satu komoditas ternak alternatif yang digunakan untuk memenuhi kebutuhan protein di Indonesia. Kadar protein daging kerbau dilaporkan lebih tinggi (20-30\%) dibandingkan dengan daging sapi (15-19\%) (Tanjung 2017). Menurut Praharani et al. (2010), ternak kerbau memiliki daya adaptasi yang lebih baik, tahan terhadap parasit eksternal pada kondisi pemeliharaan yang ekstrim (panas) dan mampu mencerna pakan yang mengandung serat kasar tinggi dengan lebih efesien. Disamping itu, ternak kerbau juga memiliki nilai ekonomis yang lebih stabil dibandingkan sapi karena harganya cenderung tidak fluktuatif (Santosa \& Fatihah 2017). Salah satu daerah yang memiliki populasi kerbau yang tinggi dan diusulkan menjadi sentral peternakan kerbau nasional adalah provinsi Banten (Tanjung 2017).

Surra yang disebabkan oleh protozoa darah Trypanosoma evansi (T. evansi) masih menjadi masalah yang serius dan menyebabkan kerugian ekonomis yang tinggi pada berbagai jenis ternak, termasuk kerbau (El-Metanawey et al. 2009; Baticados et al. 2011). Penyakit ini ditularkan oleh lalat penghisap darah, seperti Tabanus spp, Stomoxys spp, Chrysop spp dan spesies lainnya (Hagos et al. 2009). Umumnya, Surra yang menyerang kerbau bersifat kronis yang ditandai dengan penurunan bobot badan, infertilitas dan keguguran bahkan dapat menyebabkan kematian (Holland et al. 2001). Disamping itu, Surra pada sapi dan kerbau dilaporkan sering memicu terjadinya penurunan sistem imun sehingga menjadi ancaman bagi ternak tersebut untuk terinfeksi bakteri atau agen penyakit lainnya, seperti pasteurellosis dan antrak (Claes et al. 2004).

Diagnosis infeksi T. evansi atau Surra pada kerbau masih menjadi permasalahan utama di lapang. Umumnya penegakan diagnosis Surra masih tergantung pada pengamatan manifestasi klinis dan pemeriksaan ulas darah atau melakukan pemeriksaan natif secara langsung dari darah kerbau untuk melihat keberadaan parasit dibawah mikroskop (Sigh et al. 2017). Namun demikian, tingkat parasitemia yang rendah dan berfluktuasi, khususnya pada tahap infeksi kronis menjadi kendala dalam penegakan diagnosis penyakit ini. Keterbatasan metode ini dapat menyebabkan kesimpulan negatif palsu yang berakibat fatal bagi ternak. Bal et al. (2014) menyatakan bahwa lebih dari 50$80 \%$ kasus Surra tidak dapat dideteksi dengan pemeriksaan langsung dibawah mikroskop. Oleh karena itu, penegakan diagnosa Surra dan penentuan strategi pengobatannya tidak disarankan hanya berdasarkan pada teknik parasitologis saja, melainkan perlu dikonfirmasi dengan teknik diagnosa lain yang lebih tepat dan akurat yang memiliki tingkat spesifisitas dan sensitivitas yang lebih tinggi (Baticados et al. 2011).

Teknik lain yang sering digunakan untuk penegakan diagnosa Surra antara lain Micro-haematocrite Centrifugation Technique (MHCT), uji serologis dengan Card Agglutination Technique for T. evansi (CATT T. evansi), ELISA serta uji PCR (Sivajothi et al. 2014). Tehnik-teknik ini dilaporkan memiliki tingkat spesifisitas dan sensitivitas yang lebih tinggi dibandingkan dengan teknik pemeriksaan parasitologis (Bal et al. 2014).

Tujuan penelitian ini adalah untuk mendeteksi Surra pada kerbau yang terinfeksi $T$. evansi secara alami di Kabupaten Pandeglang berdasarkan empat jenis teknik diagnosa yang banyak diaplikasikan diberbagai negara. 


\section{MATERI DAN METODE}

\section{Lokasi dan sampel penelitian}

Pengambilan sampel dilakukan di tiga kecamatan yang terletak di Kabupaten Pandeglang, yaitu Kecamatan Carita, Pagelaran dan Cisata (Tabel 1). Sampel yang digunakan pada studi ini adalah darah dan serum kerbau yang dipelihara secara semi intensif. Kerbau dilepas di ladang penggembalaan pada pagi hari dan dikembalikan ke kandang pada sore hari sehingga terinfeksi T. evansi secara alami yang diduga ditularkan oleh vektor lalat penghisap darah (haematophagus flies).

Tabel 1. Lokasi pengambilan sampel darah kerbau di tiga kecamatan, Provinsi Banten

\begin{tabular}{llllc}
\hline \hline Dusun & Desa & Kecamatan & Kabupaten & Jumlah sampel \\
\hline Kalang kepeng & Sukanegara & Carita & Pandeglang & 12 \\
Cilaban & Sindang Laut & Carita & Pandeglang & 2 \\
Walang & Surakarta & Pagelaran & Pandeglang & 3 \\
Kahuripan & Sukadamai & Pagelaran & Pandeglang & 7 \\
Kapinango & Kertasana & Pagelaran & Pandeglang & 16 \\
Cikurap & Cibarani & Cisata & Pandeglang & 10 \\
\hline Total & & & & 50 \\
\hline
\end{tabular}

\section{Koleksi darah dan serum}

Pengambilan sampel darah dilakukan pada sore hari setelah kerbau dikandangkan kembali dari penggembalaan. Darah kerbau dikoleksi dari vena jugularis dengan dua jenis tabung hampa udara, yaitu tabung tanpa bahan pengendap darah (plain) dan tabung yang telah mengandung bahan pengendap darah (heparin). Sampel darah dalam tabung plain ditujukan untuk pengujian serologis (koleksi serum), sedangkan sampel dalam tabung heparin ditujukan untuk pengujian parasitologis (ulas darah, Micro-haematocrite Centrifugation Technique/MHCT) dan PCR. Masing-masing sampel darah dan serum diberi label dan disimpan didalam rak sampel pada suhu $-20^{\circ} \mathrm{C}$ untuk analisis selanjutnya (Sawitri \& Wardhana 2017).

\section{Ulas darah}

Sebanyak $5 \mu \mathrm{L}$ sampel darah segar diteteskan pada gelas obyek, selanjutnya dibuat ulas menggunakan gelas penutup (cover glass) dengan kemiringan 45 derajat. Ulas darah pada gelas obyek diangin-anginkan hingga kering kemudian difiksasi menggunakan methanol absolut selama 3 menit. Ulas darah diwarnai dengan Giemsa selama 25-30 menit. Sisa cairan pewarna Giemsa dihilangkan dengan cara mencuci gelas obyek dengan air mengalir, kemudian dikeringkan. Ulas darah yang telah diwarnai diperiksa di bawah mikroskop dengan pembesaran $400 \mathrm{X}$. Sampel dinyatakan positif apabila terdapat bentukan morfologi T. evansi pada ulas darah tersebut (Muieed et al. 2010; Singh et al. 2017). 


\section{Micro-haematocrite centrifugation technique (MHCT)}

Darah yang berasal dari tabung heparin dimasukkan ke dalam tabung mikrohematokrit berukuran $75 \times 1,5 \mathrm{~mm}$. Salah satu ujung tabung tersebut ditutup, kemudian disentrifus dengan kecepatan $12.000 \mathrm{~g}$ selama 5 menit. Sampel dinyatakan positif apabila terdapat parasit $T$. evansi pada bagian buffy-coat melalui pemeriksaan mikroskop dengan pembesaran 200 X (Holland et al. 2001).

\section{Card agglutination technique for T. evansi (CATT T. evansi)}

Uji serologis Surra dilakukan dengan menggunakan card agglutination technique for T. evansi (CATT T. evansi). Sebelum dilakukan pengujian, serum diencerkan dalam buffer CATT $T$. evansi dengan perbandingan 1 : 8. Selanjutnya, antigen kering yang terdapat didalam ampul diencerkan dengan 2,5 mL buffer dan dihomogenkan. Sebanyak $0.5 \mathrm{~mL}$ buffer dicampurkan ke dalam ampul kontrol positif dan kontrol negatif. Pengujian serologis dilakukan dengan mencampurkan $20 \mu \mathrm{L}$ sampel serum yang telah diencerkan dengan satu tetes $(45 \mu \mathrm{L})$ antigen $T$. evansi diatas lingkaran yang terdapat pada kartu (card) uji. Kemudian setiap sampel serum dan antigen dicampur dengan pengaduk plastik sampai homogen. Setiap perpindahan dari satu sampel ke sampel yang lain, pengaduk plastik dibersihkan dulu untuk menghindari kontaminasi. Setelah setiap sampel dalam lingkaran dicampur, kartu CATT T. evansi diletakkan dimesin rotasi dengan kecepatan 70 rpm selama 5 menit agar terjadi reaksi antara antibodi dalam serum dengan antigen yang ditandai dengan adanya aglutinasi (endapan seperti pasir) berwarna biru. Skor hasil reaksi uji serologis ini dibagi menjadi lima, yaitu +3 apabila reaksi aglutinasi menghasilkan endapan seperti pasir yang sangat jelas (sangat menggumpal), +2 apabila reaksi aglutinasi menghasilkan endapan seperti pasir yang jelas (cukup menggumpal), +1 apabila reaksi aglutinasi menghasilkan endapan seperti pasir yang terlihat titik titik merata pada lingkaran, +/- apabila reaksi yang terlihat sangat samar dan nyaris tidak terlihat, - apabila tidak terjadi reaksi aglutinasi antara antibodi dan antigen (Hagos et al. 2009).

\section{Ekstraksi DNA}

Ekstraksi DNA genom dilakukan menggunakan Genomic DNA Mini Kit (Geneaid) mengikuti prosedur yang telah ditetapkan oleh manufaktur. DNA genom yang telah diekstrak dimasukkan kedalam tabung Eppendorf $1.5 \mathrm{~mL}$ yang telah diberi label, selanjutnya tabung tersebut disimpan pada $-20^{\circ} \mathrm{C}$ untuk analisis selanjutnya (Sawitri \& Wardhana 2017).

\section{PCR}

Amplifikasi fragmen DNA T. evansi digunakan menggunakan dua marka genetik, yaitu ITS 1 (480 bp) dan TBR1/2 (164 bp) (Fernandez et al. 2009). Fragmen-fragmen DNA tersebut diamplifikasi menggunakan KAPA 2G Fast PCR kit (KAPA) dengan total volume per reaksi $25 \mu$ l. Kondisi PCR dan komposisi bahan kimia per reaksi untuk masing-masing marka genetik tertera pada Tabel 2. Hasil produk DNA divisualisasikan pada agar gel elektroforesis $1,5 \%$ dibawah sinar UV dengan menggunakan pewarnaan flourosafe (Geneaid). Sampel dinyatakan positif apabila terdapat pita DNA yang memiliki ukuran sesuai dengan target fragmen marka genetik. 
Tabel 2. Kondisi PCR dan susunan reagen/reaksi untuk mengamplifikasi fragmen DNA $T$. evansi berdasarkan marka genetik tertentu

\begin{tabular}{|c|c|c|c|c|c|}
\hline $\begin{array}{l}\text { Marka } \\
\text { Genetik }\end{array}$ & Sekuen & $\begin{array}{l}\text { Ukuran } \\
\text { produk }\end{array}$ & $\begin{array}{c}\text { Komposisi } \\
\text { reagen/reaksi }\end{array}$ & Kondisi PCR & Referensi \\
\hline ITS 1 & $\begin{array}{l}\text { F : } \\
\text { 5'CCGGAAGTTC } \\
\text { ACCGATATTG'3 } \\
\text { R : } \\
\text { 5'TGCTGCGTTCT } \\
\text { TCAACGAA'3 }\end{array}$ & 480 bp & $\begin{array}{l}\text { Taq } 0.5 \mathrm{U}, \\
\text { Buffer } \\
\text { (Tris/HCl) } 1 \mathrm{X} \\
\mathrm{MgCl}_{2}, 2 \mathrm{mM} \\
\mathrm{dNTPs} 200 \\
\mu \mathrm{M}, 0,2 \mu \mathrm{M} \\
\text { /per marka }\end{array}$ & $\begin{array}{l}94^{\circ} \mathrm{C}\left(5^{\prime}\right), 35 \\
\text { siklus }\left[94^{\circ} \mathrm{C}\right. \\
\left(40^{\prime \prime}\right), 58^{\circ} \mathrm{C} \\
\left(40^{\prime \prime}\right), 72^{\circ} \mathrm{C} \\
\left.\left(90^{\prime \prime}\right)\right] \text { dan } \\
72^{\circ} \mathrm{C}\left(5^{\prime}\right)\end{array}$ & $\begin{array}{l}\text { Njiru et al. } \\
2005\end{array}$ \\
\hline $\begin{array}{l}\text { TBR1/ } \\
2\end{array}$ & $\begin{array}{l}\text { F: } \\
\text { 5'GAATATTAAA } \\
\text { CAATGCGCAG'3 } \\
\text { R: } \\
\text { 5'CCATTTATTAG } \\
\text { CTTTGTTGC'3 }\end{array}$ & 164 bp & $\begin{array}{l}\text { Taq 2,5 U, } \\
\text { Buffer } \\
\text { (Tris/HCl) } 1 \mathrm{X} \\
\mathrm{MgCl}_{2}, 1,5 \\
\mathrm{mM} \text { dNTPs } \\
200 \mu \mathrm{M}, 1 \mu \mathrm{M} \\
\text { /per marka }\end{array}$ & $\begin{array}{l}94^{\circ} \mathrm{C}\left(5^{\prime}\right), 35 \\
\text { siklus }\left[94^{\circ} \mathrm{C}\right. \\
\left(40^{\prime \prime}\right), 58^{\circ} \mathrm{C} \\
\left(40^{\prime \prime}\right), 72^{\circ} \mathrm{C} \\
\left.\left(90^{\prime \prime}\right)\right] \text { dan } \\
72^{\circ} \mathrm{C}\left(5^{\prime}\right)\end{array}$ & $\begin{array}{l}\text { Muieed et } \\
\text { al. } 2010\end{array}$ \\
\hline
\end{tabular}

\section{Analisis data}

Data yang diperoleh pada penelitian ini ditabulasi dan dianalisis secara deskriptif yang disajikan dalam bentuk tabel dan grafik.

\section{HASIL DAN PEMBAHASAN}

Hasil pemeriksaan sampel darah kerbau yang terinfeksi T. evansi secara alami di Kecamatan Cisata, Pagelaran dan Carita dengan teknik parasitologis, serologis dan PCR memberikan nilai positif yang berbeda-beda (Tabel 3). Berdasarkan pemeriksaan ulas darah dan MHCT, sebanyak 16\% (8/50) sampel darah positif mengandung T. evansi, sedangkan hasil uji PCR untuk kedua primer memberikan hasil positif sebesar $50 \%$ (25/50). Pemeriksaan serologis dengan teknik CATT T. evansi menunjukkan seropositif terhadap antibodi $T$. evansi yang bersirkulasi pada kerbau di tiga kecamatan tersebut terbilang tinggi, yaitu 84\% (42/50). Setidaknya terdapat 17 (40,47\%) sampel yang tidak terdeteksi secara PCR namun positif berdasarkan uji serologis. 
Tabel 3. Hasil pengujian serum dan darah kerbau terhadap Surra yang diuji dengan berbagai jenis teknik diagnosa

\begin{tabular}{|c|c|c|c|c|c|c|c|c|}
\hline \multirow{2}{*}{ Dusun } & \multirow{2}{*}{ Desa } & \multirow{2}{*}{$\mathrm{Kec}$} & \multirow{2}{*}{$\begin{array}{l}\text { Jumlah } \\
\text { sampel }\end{array}$} & \multirow{2}{*}{ MHCT } & \multirow{2}{*}{$\begin{array}{l}\text { Ulas } \\
\text { darah }\end{array}$} & \multirow{2}{*}{$\begin{array}{l}\text { Positif } \\
\text { CATT }\end{array}$} & \multicolumn{2}{|c|}{ Positif PCR } \\
\hline & & & & & & & ITS-1 & TBR $1 / 2$ \\
\hline $\begin{array}{l}\text { Kalang } \\
\text { kepeng }\end{array}$ & Sukanegara & Carita & 12 & 4 & 4 & 12 & 6 & 6 \\
\hline Cilaban & $\begin{array}{c}\text { Sindang } \\
\text { Laut }\end{array}$ & Carita & 2 & 0 & 0 & 2 & 2 & 2 \\
\hline Walang & Surakarta & Pagelaran & 3 & 0 & 0 & 3 & 3 & 3 \\
\hline $\begin{array}{l}\text { Kahurip } \\
\text { an }\end{array}$ & Sukadamai & Pagelaran & 7 & 0 & 0 & 1 & 1 & 1 \\
\hline $\begin{array}{l}\text { Kapinan } \\
\text { go }\end{array}$ & Kertasana & Pagelaran & 16 & 0 & 0 & 15 & 5 & 5 \\
\hline Cikurap & Cibarani & Cisata & 10 & 4 & 4 & 9 & 8 & 8 \\
\hline Total & & & 50 & 8 & 8 & 42 & 25 & 25 \\
\hline
\end{tabular}

Perbedaan hasil ini dapat dipahami karena masing-masing teknik diagnosa memiliki kelebihan dan kelemahan. Ketika infeksi awal terjadi (infeksi akut), pemeriksaan dengan teknik parasitologis dan PCR akan memberikan sensitivitas yang relatif sama, yaitu sekitar 80\% (Baticados et al. 2011). Sebaliknya, tingkat sensitivitas teknik parasitologis dalam keadaan infeksi kronis hanya mencapai kurang dari 10\%, tetapi tingkat sensitivitas uji PCR meningkat menjadi dua hingga tiga kali lipat (Desquesnes \& Davila 2002). Pernyataan ini sesuai dengan hasil penelitian ini yang mendeteksi $16 \%$ positif Surra berdasarkan teknik parasitologis menjadi 50\% (tiga kali lipat lebih) melalui pemeriksaan uji PCR.

Pemeriksaan Surra dengan ulas darah dan MHCT pada studi ini memberikan nilai positif yang sama dan tergolong paling rendah dibandingkan dengan teknik yang lain. Hasil ini didukung oleh beberapa studi sebelumnya yang menyimpulkan bahwa pemeriksaan ulas darah memiliki tingkat spesifisitas cukup tinggi tetapi tingkat sensitivitasnya paling rendah (Hilali et al. 2004; Sivajothi et al. 2014; Aboed \& Faraj 2017). Ramirez-Iglesias et al. (2011) dan Tehseen et al. (2017) menyebutkan bahwa pemeriksaan ulas darah hanya efektif untuk infeksi akut ketika tingkat parasitemia tinggi. Menurut Hilali et al. (2004) bahwa keberadaan T. evansi pada kerbau mampu dideteksi pertama kali dengan teknik ulas darah pada hari ke 4 sampai 9 setelah infeksi. Teknik ini dilaporkan akan memberikan nilai positif apabila konsentrasi parasit dalam darah mencapai $10^{5}$ per milliliter dan 85 parasit per milliliter untuk teknik MHCT (Reid et al. 2001; Sigh et al. 2017). Walaupun demikian, teknik MHCT dipercaya mampu meningkatkan sensitivitas pemeriksaan ulas darah dan menurunkan potensi terjadinya negatif palsu dibandingkan dengan teknik ulas darah (Zayed et al. 2010).

Dibandingkan dengan uji CATT T. evansi, teknik PCR menunjukkan nilai positif yang lebih rendah. Namun demikian, teknik PCR terbukti lebih sensitif dibandingkan dengan ulas darah dan MHCT. Sebesar 68\% (17/25) sampel yang negatif dengan ulas darah dan MHCT, terdeteksi positif menggunakan teknik PCR. Sigh at al. (2004) menyebutkan bahwa sensitivitas teknik PCR dapat mencapai 100\% dibandingkan dengan teknik yang lain. Teknik ini mampu mendeteksi keberadaaan $T$. evansi dalam darah walaupun pada kondisi parasitemia yang rendah. Disamping itu, sampel yang positif dengan tehnik PCR mengindikasikan bahwa ternak yang diperiksa sedang terinfeksi $T$. 
evansi. Pernyataan ini didukung oleh hasil PCR dengan dua marka genetik yang berbeda. Marka TBR1/2 merupakan marka genetik $T$. evansi yang paling sensitif yang mampu mendeteksi $T$. evansi. Walaupun tingkat parasitemia sangat rendah, tetapi marka ini mampu mendeteksi dengan baik dan juga mampu mendeteksi infeksi $T$. evansi lebih awal ketika infeksi sedang terjadi.

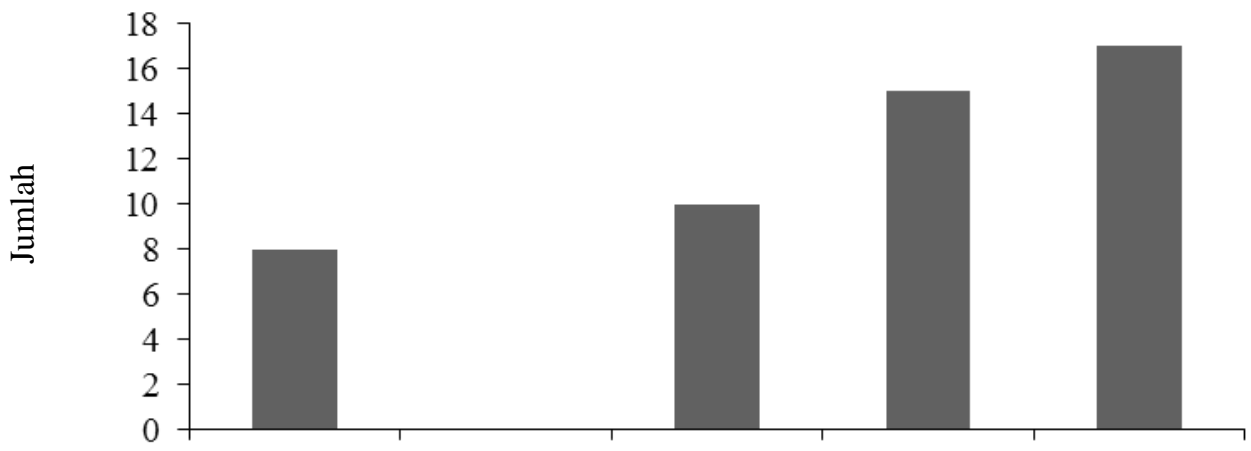

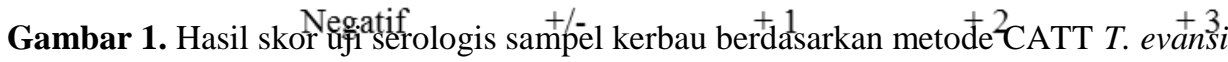

Ditinjau dari skor uji $\quad$ Skor uji serologis - CATT T. evansi $\quad$ J) kerbau yang diuji positif Surra memiliki skor +3 . Skor +2 dideteksi pada 30\% (15/30) yang diikuti dengan skor +1 sebanyak $20 \%$ (10/50). Kerbau yang dinyatakan negatif sebesar $16 \%$ (8/50). Hasil ini mengindikasikan bahwa antibodi terhadap infeksi T. evansi yang bersirkulasi pada kerbau-kerbau di Kabupaten Pandeglang cukup tinggi. Zayed et al. (2010) menyarankan agar pemeriksaan kembali dilakukan pada sampel seronegatif setelah 30 hari dari pemeriksaan pertama sehubungan dengan adanya serologi laten. Namun, hal tersebut tidak dilakukan pada penelitian karena kendala teknis pelaksanaan di lapang.

Menurut Rudramurthy et al. (2017) bahwa imunoreaktivitas CATT T. evansi pada kerbau lebih sensitif dibandingkan pada sapi. Kondisi ini diduga karena antibodi yang diproduksi pada masa infeksi aktif lebih melimpah yang selanjutnya bertanggung jawab terhadap reaksi aglutinasi antara antigen dan antibodi (OIE, 2010). Seluruh sampel positif pada pemeriksaan ulas darah juga memberikan hasil yang positif pada uji CATT T. evansi (100\%). Hasil ini sesuai dengan pernyataan Hagos et al. (2009) yang menyebutkan bahwa teknik CATT T. evansi memiliki sensitivitas lebih dari $90 \%$ pada sampel yang positif berdasarkan pemeriksaan ulas darah.

Kendati teknik CATT T. evansi menunjukkan hasil positif yang paling tinggi dibandingkan dengan yang lain, tetapi teknik ini memiliki beberapa keterbatasan. Teknik CATT T. evansi tidak mampu membedakan apakah sampel yang positif karena infeksi awal atau ternak dalam taraf penyembuhan (Fikru et al. 2015). Antibodi terhadap $T$. evansi akan terus bersirkulasi dalam darah pada ternak yang sembuh dari Surra baik sembuh dengan sendirinya (self cured) atau sembuh setelah dilakukan pengobatan (Hagos et al. 2009). Menurut Holland et al. (2004) bahwa antibodi pada kerbau pertama kali dideteksi dengan teknik CATT $T$. evansi pada hari ke 4 hingga ke 7 setelah infeksi, sedangkan Hilali et al. (2004) mendeteksinya pertama kali pada hari ke 8 setelah infeksi. Selanjutnya, titer antibodi ini akan menurun secara bertahap hingga pada hari ke 88 setelah infeksi dengan batas akhir pengenceran serum 1 : 4. Teknik CATT T. evansi sangat sesuai diaplikasikan untuk kepentingan skrining masal tetapi tetap tidak mampu menunjukkan keberadaan parasit di dalam darah (Zayed et al. 2010). 
Hasil sampel positif berdasarkan pemeriksaan ulas darah pada studi ini terbilang sangat rendah dibandingkan dengan hasil uji serologis. Hasil tersebut tergolong normal dalam suatu pengujian karena diduga antibodi yang tinggi akan menyerang parasit yang berakibat pada menurunnya jumlah parasit dalam darah, bahkan tidak mampu dideteksi pada pemeriksaan ulas darah (Pays et al. 2004). Pernyataan ini sesuai dengan pendapat Barry et al. (2015) yang menyebutkan bahwa Variant Surface Glycoprotein (VSG) Trypanosome mampu menghasilkan titer antibodi yang tinggi sehingga dapat membersihkan sekitar 99\% T. evansi dalam darah. Kejadian ini diikuti oleh pergantian antigen $T$. evansi (antigenic shift) sebagai sistem pertahanan parasit dari serangan antibodi inang.

Ditinjau dari teknik molekuler, penelitian ini menggunakan dua macam marka genetika (ITS-1 dan TBR1/2) dengan tujuan yang berbeda. Hasil visualisasi pita DNA pada kedua marka genetik ini juga berbeda. Marka ITS-1 menghasilkan pita DNA tunggal sedangkan marka TBR1/2 menghasilkan multi pita DNA (dimmers dan trimmers).

Marka ITS-1 ditujukan untuk mengetahui spesies Trypanosoma yang menginfeksi kerbau-kerbau di Kabupaten Pandeglang. Menurut Salim et al (2011) bahwa panjang produk PCR ITS-1 secara spesifik berkorelasi dengan masing-masing spesies trypanosoma sehingga dapat digunakan sebagai dasar untuk membedakan spesies. Panjang produk PCR ITS-1 dari beberapa spesies adalah sebagai berikut: $T$. congelense savannah $700 \mathrm{bp}, T$. congelense kilifi $620 \mathrm{bp}, T$. congelense forest $710 \mathrm{bp}, T$. simae 400 bp, T. simae tsavo $370 \mathrm{bp}, T$. godfreyi $300 \mathrm{bp}, T$. vivax $250 \mathrm{bp}$ sedangkan untuk T. evansi dan subspecies T. brucei (T. b. rhodesiense dan T. b. gambiense) 480 bp (Njiru et al. 2005). Penggunaan marka ITS-1 untuk mendeteksi multi infeksi Trypanosoma pada kerbau dan sapi juga pernah dilaporkan (Davilla et al. 2003). Hasil amplifikasi DNA yang diperoleh pada studi ini memiliki ukuran 480 bp yang mengindikasikan bahwa kerbau diinfeksi oleh spesies T. evansi.

Dibandingkan dengan marka genetik $T$. evansi yang lain, seperti ESAG6/7, 21/22mer dan ITS-1, marka TBR1/2 terbukti paling sensitif. Marka ini mampu mendeteksi $T$. evansi hingga konsentrasi DNA mencapai 0,001 ng pada sampel darah mencit yang diinfeksi $T$. evansi dan $0,000001 \mathrm{ng}$ pada sampel $T$. evansi yang telah dipurifikasi (Fernandez et al. 2009). Elhaig et al. (2013) juga menyatakan bahwa TBR1/2 dapat mendeteksi Surra dengan lebih efektif dibandingkan dengan ITS-1 dan RoTat 1.2 VSG serta mampu mendeteksi $T$. evansi setelah 12 jam infeksi dibandingkan dengan ITS1 (Fernandez et al. 2009). Oleh karena itu, penggunaan marka TBR1/2 ditujukan untuk mendeteksi infeksi awal $T$. evansi pada kerbau ketika parasitemia masih sangat rendah.

Walaupun teknik parasitologis memiliki tingkat sensitivitas yang rendah, tetapi teknik ini mudah, murah, cepat dan paling banyak diaplikasikan teknik di lapang. Menurut Holland et al. 2001, aplikasi teknik parasitologi sebaiknya dilakukan maksimal 3 jam setelah koleksi darah karena T. evansi tidak mampu bertahan hidup lama diluar induk semang. Berbeda dengan teknik parasitologis, aplikasi teknik PCR tidak tergantung oleh waktu selama sampel darah disimpan pada suhu $-20^{\circ} \mathrm{C}$. Sawitri et al. (2016) melaporkan aplikasi PCR dapat juga dilakukan pada sampel darah yang diteteskan pada kertas filter (whatman filter paper) sehingga lebih praktis dan tidak tergantung pada media transport atau pendingin yang jarang tersedia di lapang.

Sehubungan dengan strategi pengobatan dan pencegahan Surra terutama di daerah sentral peternakan dan daerah endemis, penegakan diagnosa Surra yang tepat sangat dibutuhkan. Apabila aplikasi teknik parasitologis memberikan hasil yang negatif, maka perlu dikonfirmasi dengan teknik yang lainnya seperti uji PCR dan serologis. Aplikasi 
teknik PCR di lapang mampu mendeteksi Surra pada fase awal infeksi dan tingkat parasitemia yang rendah. Disamping itu, penggunaan PCR tidak hanya meneguhkan diagnosa Surra secara dini, tetapi juga berpotensi sebagai piranti untuk mengeleminasi ternak atau hewan lain yang bertindak sebagai reservoir terutama ketika ternak-ternak tersebut digembalakan pada ladang yang sama.

\section{KESIMPULAN}

Penegakan diagnosis Surra didasarkan pada ditemukannya parasit T. evansi dalam darah induk semang. Sensitivitas teknik ulas darah yang rendah dapat ditingkatkan dengan cara melakukan kombinasi teknik diagnosa, seperti MHCT atau PCR. Meskipun pengujian serologis memberikan hasil seropositif yang tinggi terhadap sirkulasi antibodi pada kerbau di Kabupaten Pandeglang, namun hasil ini juga perlu dikonfirmasi dengan PCR yang memiliki sensitivitas lebih tinggi. Oleh karena itu, penegakan diagnosis Surra sebaiknya dilakukan dengan kombinasi teknik pengujian, terutama untuk ternak dengan parasitemia yang rendah sehingga hasil negatif palsu dapat dihindari dan strategi pengobatan yang akurat dapat ditentukan.

\section{UCAPAN TERIMA KASIH}

Penulis mengucapkan terima kasih kepada drh. Putut Wibowo, drh. Asmiyati Arsyad, Eko Setyo Purwanto, Edi Satria dan Farlin Nefo atas bantuan teknis selama pelaksanaan penelitian.

\section{DAFTAR PUSTAKA}

Abdoel JT, Faraj AA. 2017. Comparative studies on diagnosis of Trypanosoma evansi in camels in Al-Najaf Province, Iraq. IJSN. 8:553-556.

Bal MS, Sharma A, Ashuma, Batth BK, Kaur P, Singla LD. 2014. Detection and management of latent infection of Tryapanosoma evansi in a cattle herd. Indian J Anim Res. 48:3137.

Barry JD, Marcello L, Morrison LJ, Read AF, Lythgof K, Jones N, Carrington M, Blanding G, Bohme U, Caler E, Hertz-fowler C, Renauld H, El-sayed N, Berriman M. 2005. What the genom sequence is revealing about trypanosome antigenic variation. Biochem Soc Transactions. 33:986-989.

Baticados WN, Castro DL, Baticados AM. 2011. Parasitological and PCR detection of Trypanosoma evansi in buffaloes from Luzon, Philippines. Ceylon J Sci Bio Sci. 40:141146.

Cleas F, Radwanska M, Urakawa T, Majiwa PAO, Goddeeris B, Buscher P. 2004. Variable surface glycoprotein RoTat 1.2 PCR as a specific diagnostic tool for detection of Trypanosoma evansi infections. Kinetoplastid Biol Dis. 3:3.

Dávila AM, Herrera HM, Schlebinger T, Souza SS, Traub-Cseko YM. 2003. Using PCR for unraveling the cryptic epizootiology of livestock trypanosomosis in the Pantanal, Brazil. Vet Parasitol. 117:1-13.

Desquesnes M, Davila AMR. 2002. Application of PCR-based tools for detection and identification of animal trypanosomes: a review and perspectives. Vet Parasitol. 109:213-231. 
El-Metanawey TM, El-Beih NM, El-Aziz A, Hassanane MS, Abd El-Aziz TH. 2009. Comparative studies on diagnosis of Trypanosoma evansi in experimentally infected goats. Glob Vet. 3:348-353.

Elhaig MM, Youssef AI, El-Gayar AK. 2013. Molecular and parasitological detection of Trypanosoma evansi in camels in Ismailia, Egypt. Vet Parasitol. 198:214-218.

Fikru RF, Andualem Y, Getachew T, Menten J, Hasker E, Merga B, Goddeeris BM, Buscher P. 2015. Trypanosome infection in dromedary camels in Eastern Ethiopia: Prevalence, relative performance of diagnostic tools and host related risk factors. Vet Parasitol. 211:175-181.

Hagos A, Yilkal A, Esayass T, Alemu T, Fikru R, Feseha GAB, Goddeeris BM, Claes F. 2009. Parasitological and serological survey on trypanosomis (surra) in camels in dry and wet areas of Bale Zone, Oromyia Region, Ethiopia. Reveu Med Vet. 160:569-573.

Hilali M, Abdel-Gawad A, Nassar A, Abdel-Wahab A, Mgnus E, Buscher P. 2004. Evaluation of the card agglutination test (CATT/T. evansi) for detection of Trypanosoma evansi infection in water buffaloes (Bubalus bubalis) in Egypt. Vet Parasitol. 121:45-51.

Holland WG, Claes F, My LN, Thanh NG, Tam PT, Verloo D, Buscher P, Goddeeris B, Vecrysse J. 2001. A comparative evaluation for parasitological tests and a PCR for Trypanosoma evansi diagnosis in experimentally infected water buffaloes. Vet Parasitol. 97:23-33.

Holland WG, Thanh NG, My LN, Do TT, Goddeeris P, Vercruysse L. 2004. Prevalence of Trypanosoma evansi in water buffaloes in remote areas in northern Vietnam using PCR and serological methods. Trop Anim Health Prod. 36:45-48.

Muieed MA, Chaudhary ZI, Shakoori AR. 2010. Comparative studies on the sensitivity of polymerase chain reaction (PCR) and microscopic examination for the detection of Trypanosoma evansi in horses. Turk J Vet Anim Sci. 34:5007-5012.

Njiru ZK, Constantine CC, Guya S, Crwother J, Kiragu JM, Thompson RCA, Davila AMR. 2005. The use of ITS 1 rDNA PCR in detecting pathogenic African trypanosomes. Parasitol Res. 95:186-192.

Nurcahyo W, Yowi MRK, Hartati S, Prastowo J. 2019. The prevalence of horse trypanosomiasis in Sumba Island, Indonesia and its detection using car agglutination tests. Vet World. 12:646-652.

OIE. 2010. Trypanosoma evansi (surra) In: Manual of diagnostic tests and vaccines for terrestrial animals [Internet]. [cited 17 Mei 2019]. Available from: World Organization for Animal Health. Paris. http://www.oie.int.

Pays E, Vanhamme L, Pe'rez-morga D. 2004. Antigenic variation in Tryapanosoma brucei: facts, challenges, and mysteries. Curr Op Microbiol. 7:369-374.

Ramirez-Iglesias JR, Eleizalde MC, Gomez-Pineres E, Mendoza M. 2011. Trypanosoma evansi: A comparative study of four diagnostic techniques for trypanosomosis usingrabbit as an experimental model. Exp Parasitol. 128:91-96.

Reid SA, Husein A, Compeman PD. 2001. Evaluation and improvement of parasitological tests for Trypanosoma evansi infection. Vet Parasitol. 102:291-297.

Rudramurthy GR, Sengupta PP, Ligi M, Balamurugan V, Suresh KP, Rahman H. 2017. Serodiagnosis of animal trypanosomosis using a recombinant invariant surface glycoprotein of Trypanosoma evansi. Ind J Exp Biol. 55:209-216. 
Salim B, Bakheit MA, Kamau J, Nakamura I, Sugimoto C. 2011. Molecular epidemiology of camel tryapnosomiasis based on ITS-1 rDNA dan RoTat 1.2 VSG gene in the Sudan. Parasitol Vectors. 4:1-5.

Santosa EB, Fatihah KS. 2017. Pemberdayaan peternak kerbau di Kecamatan Maronge Kabupaten Sumbawa. J Ilmiah Wahana Bhakti Praja. 7:105-126.

Sawitri D, Wardhana AH, Dewi DA, Ekawasti F, Wijaya E. 2016. Application of dried blood sample on Whatman filter paper for detection of Trypanosoma evansi from cattle in Central Kalimantan by Internal Transcriber Spacer-1 Polymerase Chain Reaction. Proceedings of International Seminar on Livestock Production and Veterinary Technology. Denpasar (Indonesia): Indonesian Center for Animal Research and Development. doi: http://dx.doi.org/10.14334.

Sawitri DH, Wardhana AH. 2017. Genetic variability of ESAG 6/7 isolate Trypanosoma evansi. JITV. 22:38-50.

Singh N, Pathak KML, Kumar R. 2004. A comparative evaluation of parasitological, serological and DNA amplification methods for diagnosis of natural Trypanosoma evansi infection in camels. Vet Parasitol. 126:365-373.

Singh AP, Tripathi AK, Singh A, Srivastava A, Singh R. 2017. Assessment of diagnostic efficacy of various methods in detection of Trypanosoma evansi infection in buffaloes. Buff Bull. 36:147-153.

Sivajothi S, Rayulu VC, Reddy BS. 2014. Detection of Trypanosoma evansi by different methods in bovines in Andhra Pradesh. J Adv Parasitol. 3:35-38.

Tanjung CA. 2017. Analisis strategi dan model pengembangan usaha kerbau pada sentra peternakan rakyat di Kabupaten Serang Banten [Disertasi]. Institut Pertanian Bogor.

Tehseen S, Jahan N, Desquesnes M, Shahzad MI, Qamar MF. 2017. Field investigation of Trypanosoma evansi and comparative analysis of diagnostic tests in horses from Bahawalpur, Pakistan. Turk J Vet Anim Sci. 41:288-293.

Praharani L, Juarini E, Talib C, Ashari. 2010. Perkembangan populasi dan strategi pengembangan ternak kerbau. Wartazoa. 20 :119-129.

Zayed AA, Habeeb SM, Allam NAT, Ashry HMZ, Mohamed AHH, Ashour AA, Taha HA. 2010. A clinical comparative study of parasitological and serological differential diagnostic methods of Trypanosoma evansi infection in some farm animals in Egypt. Am-Eurasian J Agric Environ Sci. 8:633-642. 